\title{
PENGARUH MODEL PEMBELAJARAN KOOPERATIF TIPE INVESTIGASI KELOMPOK TERHADAP PERUBAHAN KONSEP FISIKA SISWA KELAS XI IPA DI SMA NEGERI 1 MARAWOLA PADA KONSEP USAHA DAN ENERGI
}

\author{
Siti Masita, Syamsu dan I Wayan Darmadi \\ e-mail: MasitaFKIP@gmail.com \\ Program Studi Pendidikan Fisika FKIP Universitas Tadulako \\ Jl. Soekarno Hatta Km. 9 Kampus Bumi Tadulako Tondo Palu - Sulawesi Tengah
}

\begin{abstract}
Abstrak - Penelitian ini bertujuan untuk melihat pengaruh model pembelajaran kooperatif tipe investigasi kelompok terhadap perubahan konsep fisika siswa pada konsep Usaha dan energi. Jenis penelitian yang digunakan adalah kuasi eksperimen dengan desain penelitian prates-pascates kelompok kontrol tanpa acak. Populasi dalam penelitian ini adalah seluruh siswa kelas XI IPA SMA Negeri 1 Marawola, dengan sampel penelitian kelas XI MIA 1 sebagai kelas eksperimen dengan jumlah siswa 20 orang, dan kelas XI MIA 2 sebagai kelas kontrol dengan jumlah siswa 18 orang. Instrumen yang digunakan berupa tes miskonsepsi berbentuk pilihan ganda. Berdasarkan hasil pengolahan data, diperoleh rerata skor tes awal fisika di kelas eksperimen yaitu 9,22 dan tes akhir siswa yaitu 18,30. Sedangkan rerata skor di awal fisika siswa kelas kontrol yaitu 8,80 dan tes akhir siswa yaitu 14,78 . Analisis data tes dilakukan dengan teknik statistik uji-t dua pihak (uji perbedaan rata-rata) dan analisis rata-rata perubahan konsep fisika siswa. Berdasarkan hasil penelitian diperoleh nilai hasil thitung $=2,72$ dan tabel $=2,02$. Dengan demikian $\mathrm{H}_{0}$ ditolak dan $\mathrm{H}_{1}$ diterima. Sedangkan rata-rata perubahan konsep fisika siswa pada kelas ekseperimen $=7,40$ dan kelas kontrol $=4,72$. Berdasarkan hasil uji perbedaan rata-rata dan rata-rata perubahan konsep, maka dapat dilihat bahwa perlakuan model pembelajaran kooperatif tipe investigasi kelompok yang dilakukan di kelas eksperimen lebih berpengaruh terhadap perubahan konsep siswa dibandingkan dengan pembelajaran inkuiri yang diberikan di kelas kontrol. Hal ini dapat disimpulkan bahwa terdapat pengaruh model pembelajaran kooperatif tipe investigasi kelompok terhadap perubahan konsep fisika siswa kelas XI IPA di SMA Negeri 1 Marawola.
\end{abstract}

Kata Kunci : Model Pembelajaran kooperatif tipe investigasi kelompok, perubahan konsep.

I. PENDAHULUAN

Kemampuan memahami konsep dalam pembelajaran fisika merupakan syarat mutlak dalam mencapai keberhasilan belajar fisika. Hanya dengan penguasaan konsep fisika seluruh permasalahan fisika dapat dipecahkan, baik permasalahan fisika yang ada dalam kehidupan sehari-hari maupun permasalahan fisika dalam bentuk soal-soal fisika di sekolah.

Sebelum melakukan proses pembelajaran fisika di sekolah, siswa telah membawa sebuah konsep awal yang mereka peroleh melalui kehidupan mereka sehari-hari. Konsep yang mereka pahami ini kadang sesuai kadangkala juga keliru atau bertentangan dengan konsep fisika yang sesungguhnya. Konsep yang keliru ini dikenal dengan istilah miskonsepsi atau salah konsep. Miskonsepsi siswa ini dapat diluruskan dalam pendidikan formal dengan cara melakukan perubahan konseptual.

Biasanya cukup susah untuk merubah pandangan siswa dari konsep awalnya yang keliru ke konsep ilmiah, sebab menurut mereka konsep awal yang mereka anut lebih sesuai dengan pengamatan dan pengalaman yang mereka peroleh dalam kehidupan mereka sehari-hari (lebih sesuai dengan logika mereka). Misalnya tentang pernyataan bahwa 'bumi tidak berbentuk bulat melainkan berbentuk datar', 'massa sama dengan berat', dan masih banyak lagi contoh lainnya. ${ }^{[1]}$

Adakalanya ketika siswa diberi soal sederhana tentang rumus mereka dapat menyelesaikannya dengan mudah. Tetapi ketika diberi soal dalam bentuk konsep siswa terlihat kesulitan ketika menyelesaikan soal tersebut. Akibatnya ketika diberi soal rumus 
ISSN 23383240

yang agak mengecoh mereka tidak dapat menyelesaikan soal tersebut. Hal ini menggambarkan jika pola belajar siswa lebih cenderung menghapal dibandingkan memahami apa yang diajarkan. Hal inilah yang menjadi salah satu penyebab siswa kesulitan untuk merubah miskonsepsinya.

Pembelajaran perubahan konseptual yang mendasarkan diri pada paham konstruktivisme, sesungguhnya adalah model pembelajaran yang berbasis keterampilan berpikir. Pembelajaran perubahan konseptual memfasilitasi siswa untuk berpartisipasi aktif mengkonstruksi pengetahuannya. Dalam proses tersebut, siswa menguji dan mereview ideidenya berdasarkan pengetahuan awal yang telah dimiliki, menerapkannya dalam situasi yang baru, dan mengintegrasikan pengetahuan tersebut kestruktur kognitif yang dimiliki. [2]

Brook dalam Santyasa [3] menyatakan bahwa pengetahuan yang telah dimiliki oleh seseorang sesungguhnya berasal dari pengetahuan yang secara spontan diperoleh dari interaksinya dengan lingkungan. Sementara pengetahuan baru dapat bersumber dari intervensi di sekolah yang keduanya bisa konflik, kongruen, atau masing-masing berdiri sendiri. Dalam kondisi konflik kognitif, siswa dihadapkan pada tiga pilihan, yaitu: mempertahankan intuisinya semula, (2) merevisi sebagian intuisinya melalui proses asimilasi, dan (3) merubah pandangannya yang bersifat intuisi tersebut dan mengakomodasikan pengetahuan baru. Perubahan konseptual terjadi ketika siswa memutuskan pada pilihan yang ketiga. Agar terjadi proses perubahan konseptual, belajar melibatkan pembangkitan dan restrukturisasi konsepsi-konsepsi yang dibawa oleh siswa sebelum pembelajaran.

Jacob, et al dalam Santyasa [3] menyatakan pemikiran Dewey yang utama tentang pendidikan, adalah: (1) siswa hendaknya aktif, learning by doing; (2) belajar hendaknya didasari motivasi intrinsik; (3) pengetahuan adalah berkembang, tidak bersifat tetap; (4) kegiatan belajar hendaknya sesuai dengan kebutuhan dan minat siswa; (5) pendidikan harus mencakup kegiatan belajar dengan prinsip saling memahami dan saling menghormati satu sama lain, artinya prosedur demokratis sangat penting; (6) kegiatan belajar hendaknya berhubungan dengan dunia nyata.

Slavin dalam Santyasa [3] menjelaskan bahwa model pembelajaran kooperatif tipe investigasi kelompok memiliki enam langkah pembelajaran, yaitu: (1) grouping (menetapkan jumlah anggota kelompok, menentukan sumber, memilih topik, merumuskan permasalahan), (2) planning (menetapkan apa yang akan dipelajari, bagaimana mempelajari, siapa melakukan apa, apa tujuannya), (3) investigation (saling tukar informasi dan ide, berdiskusi, klarifikasi, mengumpulkan informasi, menganalisis data, membuat inferensi), (4) organizing (anggota kelompok menulis laporan, merencanakan presentasi laporan, penentuan penyaji, moderator, dan notulis), (5) presenting (salah satu kelompok menyajikan, kelompok lain mengamati, mengevaluasi, mengklarifikasi, mengajukan pertanyaan atau tanggapan), dan (6) evaluating (masing-masing siswa melakukan koreksi terhadap laporan masing-masing berdasarkan hasil diskusi kelas, siswa dan guru berkolaborasi mengevaluasi pembelajaran yang dilakukan, melakukan penilaian hasil belajar yang difokuskan pada pencapaian pemahaman. Khasanah ${ }^{[4]}$ menyatakan bahwa konsep materi Usaha dan Energi cukup kompleks sebab memuat konsep-konsep yang saling berkaitan, sehingga memungkinkan terjadi miskonsepsi.

Penelitian yang pernah dilakukan Evi. I.S, Diane, $\mathrm{N}$ dan Marmi, S. [5] menunjukkan bahwa bahwa masih banyak ditemui miskonsepsi siswa pada konsep Usaha dan Energi di Kelas XI IPA (tingkat SMA/sederajat).

Suartika, Arnyana, dan Setiawan [6] dalam hasil penelitiannya menyimpulkan bahwa terdapat perbedaan pemahaman konsep dan keterampilan berpikir kreatif siswa antara siswa yang mengikuti pembelajaran group investigation dengan siswa yang belajar dengan model pembelajaran siklus belajar.

\section{METODE PENELITIAN}

Jenis penelitian yang digunakan pada penelitian kali ini dilihat dari teknik yang digunakan adalah penelitian kuasi eksperimen. Penelitian kuasi eksperimen berfungsi untuk mengetahui pengaruh percobaan atau 
perlakuan terhadap karakteristik subjek yang diinginkan oleh peneliti.

Adapun desain penelitian yang digunakan yaitu desain prates-pascates kelompok kontrol tanpa acak [7]. Desain penelitian yang digunakan dapat dilkukiskan seperti pada Tabel 1.

Tabel 1 Desain Prates-Pascates Kelompok Kontrol Tanpa Acak

\begin{tabular}{cccc}
\hline Kelompok & Prates & Perlakuan & Pascates \\
\hline E & $\mathrm{T}_{1}$ & $\mathrm{X}$ & $\mathrm{T}_{2}$ \\
$\mathrm{C}$ & $\mathrm{T}_{1}$ & - & $\mathrm{T}_{2}$
\end{tabular}

Keterangan:

$X$ : Perlakuan dengan model pembelajaran kooperatif tipe investigasi kelompok

$\mathrm{T}_{1}$ : Tes awal

$\mathrm{T}_{2}$ : Tes akhir

$\mathrm{T}_{1}=\mathrm{T}_{2}$

Penelitian dilakukan di SMA Negeri 1 Marawola, Jalan Palu-Bangga No.84 Binangga. Penelitian dilaksanakan pada bulan NovemberDesember 2014. Populasi dalam penelitian ini adalah seluruh siswa kelas XI IPA SMA Negeri 1 Marawola tahun pelajaran 2014/2015 yang terdiri dari 3 kelas. Sampel dalam penelitian ini adalah kelas XI MIA 1 dan MIA 2. Teknik pengumpulan sampel yang digunakan adalah purposive sampling, yaitu teknik penentuan sampel dengan pertimbangan tertentu.

\section{HASIL DAN PEMBAHASAN}

Analisis Instrumen

Berdasarkan hasil analisis validitas item, dari 26 nomor soal yang diujikan, diketahui 20 diantaranya diterima, artinya layak untuk diujikan pada siswa. Sedangkan 5 nomor soal lainnya diputuskan untuk direvisi, artinya soal tersebut dapat diujikan dengan catatan soal telah diperbaiki baik dari segi isi maupun konstruksinya. Peneliti merevisi 5 nomor soal yang perlu direvisi, sehingga total soal yang diujikan untuk tes awal dan tes akhir dikelas eksperimen maupun kelas kontrol berjumlah 25 soal.

\section{Uji Normalitas}

Pengujian data normalitas data penelitian ini peneliti menggunakan Chi-kuadrat dengan kriteria penerimaan $X^{2}$ hitung $<X^{2}$ tabel, taraf signifikan $\alpha=0,05$, dan derajat kebebasan $\mathrm{dk}=\mathrm{k}-3$. Data yang digunakan untuk menguji normalitas data meliputi tes awal dan tes akhir hasil belajar baik kelas eksperimen maupun kelas kontrol. Hasil uji normalitas tes awal dan tes akhir dari kelas eksperimen dan kelas kontrol dapat dilihat pada Tabel 2.

Tabel 2 Hasil Uji Normalitas Tes Awal dan Tes

Akhir Kelas Eksperimen dan Kelas Kontrol

\begin{tabular}{ccccc}
\hline \multirow{2}{*}{ Uraian } & \multicolumn{2}{c}{ Tes Awal } & \multicolumn{2}{c}{ Tes Akhir } \\
\cline { 2 - 6 } & \multicolumn{2}{c}{ EksperimenKontrolEksperimenKontrol } \\
\hline Sampel & 20 & 18 & 20 & 18 \\
$\mathbf{x}_{\text {Hitung }}^{2}$ & 4,06 & 4,88 & 2,47 & 4,93 \\
\hline $\mathbf{x}_{\text {tabel }}^{2}$ & 7,81 & 4,81 & \\
Ket & Normal & \multicolumn{2}{c}{ Normal } \\
\hline
\end{tabular}

Berdasarkan uji normalitas pada Tabel 2 dengan menggunakan Chi-kuadrat dengan kriteria penerimaan $X^{2}$ hitung $<X^{2}(1-a)(k-3)$, dimana untuk tes awal baik kelas eksperimen maupun kelas kontrol nilai $X^{2}$ hitung lebih kecil daripada nilai $X^{2}(1-a)(k-3)$. Begitupula untuk tes akhir, nilai $X^{2}$ hitung lebih kecil daripada nilai $X^{2}{ }_{(1-}$ a) $(k-3)$, baik di kelas eksperimen maupun kelas kontrol. Artinya, data tes awal dan tes akhir baik di kelas eksperimen maupun kelas kontrol terdistribusi normal.

Uji Homogenitas

Pengujian data homogenitas menggunakan uji-F dengan kriteria jika $F_{\text {hitung }}<$

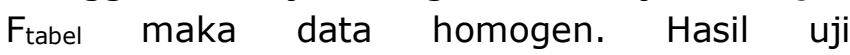
homogenitas dari kelas eksperimen dan kelas kontrol dapat dilihat pada Tabel 3.

Tabel 3. Hasil Uji Homogenitas Tes Awal dan

\begin{tabular}{|c|c|c|c|}
\hline \multicolumn{4}{|c|}{ Tes Akhir } \\
\hline Uraian & $\begin{array}{c}\text { Tes } \\
\text { awal }\end{array}$ & $\begin{array}{l}\text { Tes } \\
\text { Akhir }\end{array}$ & Ket \\
\hline$F_{\text {hitung }}$ & 0,99 & 1,66 & Homogen \\
\hline Ftabel & 2,19 & 2,19 & 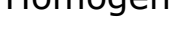 \\
\hline
\end{tabular}

Berdasarkan Tabel 3, nilai $F_{\text {hitung }}<F_{\text {tabel. }}$ Hal ini menunjukkan bahwa data tersebut memiliki varians yang sama (homogen).

Uji Hipotesis

1) Uji Perbedaan Rata-Rata

Pengujian hipotesis ini menggunakan statistik parametrik uji-t (uji dua pihak). Data hasil pengujian statistik tes awal dan tes akhir dapat dilihat pada Tabel 4 dan Tabel 5. 
Tabel 4: Uji Hipotesis Tes Awal

\begin{tabular}{|c|c|c|c|c|c|}
\hline No & Kelas & $\overline{\mathbf{X}}$ & $t_{\text {hitung }}$ & $\begin{array}{c}t_{\text {tabel }} \\
(\alpha=0,0 \\
5)\end{array}$ & $\begin{array}{c}\text { Keputusa } \\
n\end{array}$ \\
\hline 1 & $\begin{array}{l}\text { Eksperime } \\
\mathrm{n}\end{array}$ & 9,22 & 0,60 & 2,02 & $\begin{array}{c}\mathrm{H}_{\mathbf{0}} \\
\text { diterim }\end{array}$ \\
\hline
\end{tabular}

Berdasarkan data pada Tabel 4 dengan kriteria pengujian dimana $\mathrm{H}_{0}$ diterima jika $\mathrm{t}<$ $\mathrm{t}_{(1-\mathrm{a})}$ pada taraf signifikansi $\mathrm{a}=0,05$ dan $\mathrm{dk}=36$, diperoleh $\mathrm{t}_{0,95(46)}=2,02$. Berdasarkan hasil perhitungan diketahui $0,60<2,02$. Hal ini menunjukkan bahwa nilai thitung berada pada daerah penerimaan $\mathrm{H}_{0}$. Artinya tidak terdapat perbedaan hasil perubahan konseptual siswa antara kelas eksperimen dengan kelas kontrol. Artinya sebelum diberi perlakuan, kemampuan awal siswa pada kelas eksperimen dan kelas kontrol tidak berbeda jauh.

Tabel 5 Uji Hipotesis Tes Akhir

\begin{tabular}{|c|c|c|c|c|}
\hline No & Kelas & $\bar{X} \quad$ thitung & $\begin{array}{c}t_{\text {tabel }} \\
(\alpha=0,05)\end{array}$ & $\mathrm{Ke}$ \\
\hline 1 & Eksp & 7 18,30 & & , \\
\hline 2 & Kontrol & $14,78^{2, / 2}$ & & diterima \\
\hline
\end{tabular}

Berdasarkan Tabel 5 titung $>$ tabel atau 2,72 > 2,02. Hal ini berarti, nilai thitung berada diluar daerah penerimaan $\mathrm{H}_{0}$. Dengan demikian $\mathrm{H}_{0}$ ditolak dan $\mathrm{H}_{1}$ diterima. Hal ini menunjukkan bahwa terdapat perbedaan hasil perubahan konseptual antara kelas eksperimen dengan kelas kontrol. Hasil perubahan konseptual siswa pada kelas eksperimen lebih tinggi daripada kelas kontrol. Artinya terdapat pengaruh model pembelajaran kooperatif tipe investigasai kelompok terhadap perubahan konseptual fisika siswa dikelas eksperimen.

\section{Analisis Perubahan Konsep}

Perubahan konsep siswa dapat dilihat dengan membandingkan hasil jawaban siswa tiap satu nomor soal pada tes awal dan tes akhir ketika di beri perlakuan model pembelajaran kooperatif tipe investigasi kelompok. Rata-rata perubahan konseptual siswa pada kelas eksperimen dan kelas kontrol dapat dilihat pada Tabel 6 .
Tabel 6 Rata-Rata Perubahan Konsep Kelas Eksperimen dan Kelas Kontrol

\begin{tabular}{clc}
\hline No & Kelas & $\begin{array}{c}\text { Perubahan } \\
\text { Konsep }\end{array}$ \\
\hline 1 & Eksperimen & 7,40 \\
2 & Kontrol & 4,72 \\
\hline
\end{tabular}

Berdasarkan Tabel 6, ketika diberi tes awal terlihat bahwa lebih banyak siswa yang memilih option salah dibandingkan option benar. Hal ini menunjukkan bahwa sebelum diberi perlakuan pada kelas eksperimen dan kelas kontrol, masih banyak siswa yang mengalami miskonsepsi.

Secara kuantitatif, rata-rata perubahan konsep siswa dikelas ekseperimen lebih tinggi daripada kelas kontrol. Berdasarkan hasil uji perbedaan rata-rata pada Tabel 5 dan analisis perubahan konsep pada Tabel 6, maka dapat disimpulkan bahwa perlakuan model pembelajaran kooperatif tipe investigasi kelompok lebih berpengaruh terhadap perubahan konsep fisika siswa dibandingkan dengan pembelajaran inkuiri yang diberikan di kelas kontrol

Pembahasan

Berdasarkan hasil pengujian hipotesis yang telah dihitung memberikan jawaban pada peneliti bahwa terdapat perbedaan skor tes akhir antara kelas eksperimen dengan kelas kontrol. Nilai uji perbedaan rata-rata dengan taraf nyata $\mathrm{a}=0,05$ diperoleh besar thitung $=$ 2,72 dan tabel $=2,02$, artinya thitung $>t_{\text {tabel, }}$, maka hipotesis nol $\left(\mathrm{H}_{0}\right)$ ditolak dan hipotesis satu $\left(\mathrm{H}_{1}\right)$ diterima. Dari data tersebut terlihat bahwa hasil perubahan konseptual kelas eksperimen yang diberi perlakuan model pembelajaran kooperatif tipe investigasi kelompok lebih tinggi daripada kelas kontrol yang diberi perlakuan pembelajaran inkuiri. Hal ini menunjukkan bahwa model pembelajaran kooperatif tipe investigasi kelompok dapat berpengaruh terhadap perubahan konseptual fisika siswa.

Berdasarkan hasil tes awal dapat dilihat beberapa miskonsepsi untuk konsep usaha dan energi yang ada pada siswa. Miskonsepsi yang ditemukan pada konsep usaha adalah sebagian besar siswa menganggap bahwa 
ISSN 23383240

benda yang ditarik ke kiri maka usahanya akan selalu bernilai negatif, tanpa melihat arah perpindahan benda tersebut. Siswa juga masih rancu dalam membedakan usaha yang bernilai positif, negatif dan nol. Siswa mengganggap jika kita mengeluarkan kerja maka kita melakukan usaha, tanpa melihat keadaan benda apakah bergerak atau tidak, serta arah perpindahannya. Ketika melihat besar usaha yang dikerjakan pada benda, siswa menganggap usaha selalu dipengaruhi oleh lintasan benda, dan mengabaikan perpindahan benda. Siswa belum memahami pengaruh sudut terhadap usaha yang dilakukan.

Miskonsepsi yang ditemukan pada konsep energi adalah sebagian besar siswa menganggap benda yang diam tidak memiliki energi. Siswa menganggap energi kinetik selalu dipengaruhi oleh gaya gravitasi bumi. Semakin besar gaya gravitasi bumi, maka semakin besar pula energi kinetik benda. Semakin tinggi posisi benda, maka semakin besar energi kinetik benda, sedangkan energi potensial semakin besar. Siswa juga keliru dalam memahami pengaruh gaya konservatif terhadap energi mekanik. Seperti pada soal no 15, meskipun gaya konservatif berlaku, siswa mengganggap balok yang akan sampai ke dasar lebih dulu adalah balok-b, kemudian balok-a manyusul balok-c. Siswa belum memahami bahwa jika gaya non konservatif diabaikan, maka ketiga balok tersebut akan mencapai dasar secara bersamaan.

Berdasarkan hasil tes akhir, terlihat bahwa siswa lebih banyak yang memilih option benar atau pilihan yang sesuai dengan konsep ilmiah fisika yang sebenarnya, daripada siswa yang memilih option keliru. Hal ini menunjukkan bahwa setelah diberikan perlakuan model pembelajaran kooperatif tipe investigasi kelompok siswa dapat merubah miskonsepsi mereka ke konsep ilmiah yang sebenarnya. Siswa yang memilih option keliru dapat dikatakan bahwa siswa tersebut belum mampu merubah miskonsepsinya, atau bahkan tidak mengetahui konsep sama sekali.

Model pembelajaran kooperatif tipe investigasi kelompok efektif untuk merubah miskonsepsi siswa ke konsep ilmiah fisika yang sebenarnya, sebab pembelajaran ini dapat mengubah siswa dari belajar yang hanya mendengarkan dan menerima informasi dari guru menjadi belajar dengan banyak berpikir. Kebiasaan siswa yang hanya menghafal atau mengingat konsep berubah menjadi memahami konsep secara mendalam karena mereka sendiri yang menemukannya.

Berdasarkan hasil penelitian ini, menunjukkan bahwa suasana belajar yang mendukung merupakan salah satu motivasi bagi siswa dalam belajar. Oleh sebab itu, dalam proses belajar mengajar guru terus berupaya menerapkan pembelajaran yang dapat mengaktifkan siswa sehingga pembelajaran fisika menjadi lebih bermakna bagi siswa, sehingga siswa senang belajar fisika, dan pada akhirnya akan mendapatkan pemahaman yang lebih baik dan hasil belajar siswa lebih meningkat.

Kelebihan model pembelajaran kooperatif tipe investigasi kelompok adalah miskonsepsi siswa dapat diketahui terlebih dahulu oleh peneliti sehingga dalam pemecahan masalah konsep peneliti lebih mudah menuntun siswa untuk merubah miskonsepsinya. Selain itu, pembelajaran ini dapat memberikan kesempatan kepada siswa untuk lebih aktif mengembangkan kemampuan dan kreativitasnya sendiri secara mandiri, bertanggung jawab baik secara individual maupun kelompok, saling bekerja sama dan melakukan penemuannya sendiri. Siswa lebih memahami belajar secara lebih mudah, dan memperkuat penyimpanan materi yang telah disampaikan kepada siswa.

Kekurangan dari pembelajaran ini adalah masalah alokasi waktu, sebab dalam pelaksanaannya ketika proses investigasi relatif lama, terutama ketika melakukan eksperimen dan mengerjakan LKS karena siswa lebih banyak menggali referensi di internet. Untuk itu waktu yang digunakan harus dimanfaatkan semaksimal mungkin.

Penelitian yang pernah dilakukan sehubungan dengan perubahan konseptual adalah penelitian yang dilakukan Santyasa (2008) dengan membandingkan beberapa model pembelajaran. Ternyata pemahaman konsep siswa dapat lebih dikembangkan 
ISSN 23383240

dengan pembelajaran perubahan konseptual disetting model pembelajaran kooperatif tipe investigasi kelompok daripada disetting dengan model pembelajaran kooperatif tipe STAD.

\section{KESIMPULAN}

Berdasarkan hasil penelitian dan analisis data yang diperoleh, maka dapat disimpulkan bahwa model pembelajaran koopertif tipe investigasi kelompok dapat mempengaruhi perubahan konseptual fisika siswa kelas XI IPA di SMA Negeri 1 Marawola pada konsep Usaha dan Energi. Hal ini dapat dilihat dari hasil pengujian statistik, dimana thitung $>t_{\text {tabel }}$ atau $2,72>2,02$. Artinya, $\mathrm{H}_{0}$ ditolak dan $\mathrm{H}_{1}$ diterima. Perlakuan model pembelajaran kooperatif tipe investigasi kelompok lebih berpengaruh terhadap perubahan konsep siswa dibandingkan dengan pembelajaran inkuiri yang diberikan di kelas kontrol

\section{UCAPAN TERIMA KASIH}

Penyusun sadar bahwa penyusunan jurnal ini tidak terlepas dari bantuan berbagai pihak. Untuk itu, terima kasih yang sebesarbesarnya penyusun sampaikan kepada bapak Drs. H. Kamaluddin M.Si selaku pembahas I dan bapak Drs. Fihrin, M.Si selaku pembahas II yang telah memberikan saran yang sangat bermanfaat selama seminar proposal dan seminar hasil yang sangat membantu dalam penyusunan jurnal ini.

\section{DAFTAR PUSTAKA}

[1] Suparno, P. (2013). Miskonsepsi dan Perubahan Konsep Dalam Pendidikan Fisika. Jakarta: PT Gramedia Widiasarana Indonesia.

[2] Santyasa, I.W. (2008). "Pengembangan Pemahaman Konsep Dan Kemampuan Pemecahan Masalah Fisika Bagi Siswa SMA Dengan Pemberdayaan Model Perubahan Konseptual Bersetting Investigasi Kelompok". e-Journal Program Pascasarjana Universitas Pendidikan Ganesha Program Studi IPA. 1,(1), 3-12.

[3] Santyasa, I Wayan. (2007). "Makalah Model-Model Pembelajaran Inovatif".
Disajikan dalam pelatihan tentang

Penelitian

Tindakan Kelas

bagi Guru-Guru SMP dan SMA di Nusa Penida, tanggal 29 Juni s.d 1 Juli 2007

[4] Khasanah, N. (2010). "Penggunaan Pendekatan Konflik Kognitif Untuk Remediasi Miskonsepsi Pembelajaran Usaha dan Energi". Magister pada PPS Universitas Sebelas Maret Surakarta: Tidak diterbitkan.

[5] Evi. I.S, Diane, N dan Marmi, S. (2009). "Konsepsi Siswa Tentang Usaha dan Energi". Strata-1 pada Universitas Kristen Satya Wacana Salatiga: Tidak diterbitkan

[6] Suartika. A dan Setiawan. (2013). "Pengaruh Model Pembelajaran Kooperatif Tipe Group Investigation (GI) Terhadap Pemahaman Konsep Biologi dan Keterampilan Berpikir Kreatif Siswa Sma". e-Journal Program Pascasarjana Universitas Pendidikan Ganesha. 3, (2), 27-34

[7] Sudjana. N dan Ibrahim. 2009. Penelitian dan Penilaian Pendidikan. Bandung : Sinar Baru Algesindo. 